\title{
Improvement of Near Vision for Low Vision Patients in National Eye Healthcare Center Cicendo Eye Hospital 2010-2011
}

\author{
Muhammadnur Rachim Enoch ${ }^{1}$, Ine Renata Musa ${ }^{2}$, Titing Nurhayati ${ }^{3}$ \\ ${ }^{1}$ Faculty of Medicine, ${ }^{2}$ Department of Ophthalmology, Faculty of Medicine, Universitas Padjadjaran/ \\ National Eye Center Cicendo Hospital Bandung, ${ }^{3}$ Department of Physiology, Faculty of Medicine, \\ Universitas Padjadjaran
}

\begin{abstract}
Background: "Low vision" is a term used refer to a person having a visual acuity of less than 6/18 (20/60) to light perception (LP). People with low vision can still be treated to perceive or see objects, although several limitations occur. Treatments for people with low vision include either optical or non-optical devices. This research aims to reveal visual acuity for near vision that can serve as corrective benchmark after devices for near vision are given.

Methods: This is a retrospective descriptive research, using medical records from the National Eye Healthcare Center, Cicendo Eye Hospital, for the period of August 2010-September 2011 as the subject of the research. Approximately 475 patients were listed, 263 female and 212 male. The number of patients with low vision given with corrective device for near vision were 81 patients.

Results: The result showed that visual acuity was corrected after corrective devices for near vision with the size of 1-10 M were given.

Conclusions: The highest of overall corrections or improvements for near vision are the one under the category of "severe visual impairment". [AMJ.2014;1(2):94-9]
\end{abstract}

Keywords: Low vision, optical devices, visual acuity

\section{Peningkatan Penglihatan Jarak Dekat Pada Penderita“ Low Vision" di RS Mata Nasional Cicendo 2010-2011}

\begin{abstract}
Abstrak
Latar Belakang: "Low vision" adalah istilah yang mengacu pada seseorang yang memiliki ketajaman visual kurang dari 6/18 (20/60) dengan persepsi cahaya. Orang dengan low vision masih dapat diobati untuk melihat benda meskipun dengan berbagai keterbatasan. Pengobatan terhadap penderita low vision meliputi perangkat optik atau non-optik.. Penelitian ini bertujuan untuk menggambarkan ketajaman visual penglihatan dekat yang dapat berfungsi sebagai pedoman perbaikan setelah perangkat diberikan.

Metode: Penelitian ini merupakan penelitian deskriptif retrospektif dengan menggunakan rekam medis dari Pusat Mata Nasional Kesehatan, RS Mata Cicendo, periode Agustus 2010-September 2011 sebagai subjek penelitian. Sekitar 475 pasien yang terdaftar terdiri atas 263 perempuan dan 212 laki-laki, 81 diantaranya diberikan perangkat korektif untuk penglihatan dekat.

Hasil: Ketajaman visual dapat diperbaiki setelah dilakukan pemberian perangkat korektif untuk penglihatan jarak dekat dengan ukuran 1-10 M.

Simpulan: Peningkatan penglihatan jarak dekat terbaik adalah pada kelompok low vision yang termasuk kategori "gangguan penglihatan berat". [AMJ.2014;1(2):94-9]
\end{abstract}

Kata kunci: Low vision, perangkat optik, ketajaman visual

Correspondence: Muhammadnur Rachim Enoch, Faculty of Medicine, Universitas Padjadjaran, Jalan Raya BandungSumedang Km.21, Jatinangor, Sumedang, Indonesia, Phone: +628212098 5470, Email: muhammadnurrachim@gmail. com 


\section{Introduction}

Low vision is one of the severe visual or optical issues aside from blindness. According to the WHO, low vision is a term used refer to a person having a visual acuity of less than 6/18 (20/60) to light perception (LP), or having a visual field of less than 10 degrees from the fixation point that cannot be treated or corrected only with standard refractive devices. ${ }^{1}$ Low vision is different than blindness; people with low vision can still be treated, although several limitations occur. ${ }^{2}$

People with low vision can come from any age. According to a study conducted by the WHO, approximately 285 million people across the world were suffering from visual impairment, whereas 39 million suffered from blindness and others from low vision. ${ }^{1}$ In the United States of America, the number of people with low vision has reached 2.4 million. According to studies in Indonesia, people with low vision have a relatively high prevalence, which is around 9/10.000 children, or approximately 210,000 children in Indonesia. ${ }^{3}$ In 1987, a study was conducted in Bandung, resulting in the conclusion that $1.56 \%$ of children in elementary school s, or approximately 70,200 children, were suffering from low vision. ${ }^{4}$

According to The International Classification of Disease, $9^{\text {th }}$ Revision, Clinical Modification, Low Vision, people with low vision are classified into several categories: moderate visual impairment, severe visual impairment, profound visual impairment, near total visual loss, and total blindness. Such classification is based on visual acuity; hence treatments are also affected. ${ }^{5-8}$

Treatments for people with low vision come in various kinds, including either optical or non-optical devices. Optical devices are deemed the most efficient for people with low vision since such devices can improve the visual quality and thus decrease dependences on other people. Most of the notable nonoptical devices are books with large fonts, reading stands, and reading light. On the other hand, there are many kinds of optical devices , such as magnifierfor near vision, and telescopes for distance vision. ${ }^{9}$

In the study conducted by Hinds et al. ${ }^{10}$ in England, it was concluded that there were improvements on life quality among patients after they had been given corrective devices for near vision, allowing them to read books, newspapers, price tags, and tickets easily.

Therefore, It was interested in revealing the visual acuity for near vision which could provide improvements and corrections when several optical devices such as magnifiers were given to the patients with low vision at Cicendo Eye Hospital.

\section{Methods}

This descriptive cross-sectional study was This research used medical records of patients with low vision at the National Eye Center, Cicendo Eye Hospital, for the period of August 2010September 2011 as the subject of research, which fulfilled both inclusion and exclusion criteria. The inclusion criteria were medical records of patients with low vision with visual acuity of 6/18 to light perception at Refraction, Low Vision, Contact Lens Clinic, National Eye Center, Cicendo Eye Hospital, whereas the exclusion criteria were incomplete medical records.

This research used the retrospectivedescriptive method, using medical records from Cicendo Eye Hospital. The collected data included patients' identifications (name, age, and sex), visual acuity, and corrective devices given. The descriptive method was used, displayed and presented in frequency distribution tables and graphics.

\section{Results}

It can be inferred that the overall number of patients treated for a year at Refraction, Low Vision, and Contact Lenses Clinic was 475 patients, with 212 male patients (44.63\%) and 263 female patients (55.37\%) (Table 1$)$.

Most of the patients with low vision for a year were under the age of 11-20 years old (24.21\%). The lowest number was under the aged of above 80 years old $(0.63 \%)$

The patients with low vision who were given a device for near vision were 81 patients or $17.05 \%$, whereas those who were not given such devices were 394 patients or $82.95 \%$ (figure 1).

Patients with low vision having

\section{Table 1 Demographic Data Distribution of Patients with Low Vision, Based on} Sex

\begin{tabular}{ccc|}
\hline Sex & Frequency & Percentage \\
\hline Male & 212 & $44.63 \%$ \\
Female & 263 & $55.37 \%$ \\
\hline
\end{tabular}


Table 2 Frequency Distribution of Patients with Low Vision, Based on Age

\begin{tabular}{ccc}
\hline Age (Years old) & Frequency & Percentage \\
\hline $0-10$ & 70 & $14.74 \%$ \\
$11-20$ & 115 & $24.21 \%$ \\
$21-30$ & 94 & $19.79 \%$ \\
$31-40$ & 77 & $16.21 \%$ \\
$41-50$ & 44 & $9.26 \%$ \\
$51-60$ & 35 & $7.37 \%$ \\
$61-70$ & 20 & $4.21 \%$ \\
$71-80$ & 17 & $3.58 \%$ \\
$>80$ & 3 & $0.63 \%$
\end{tabular}

improvements after given low vision device were 66 patients $(81.48 \%)$, whereas patients with no improvements whatsoever were 15 patients (18.52\%) (figure 2).

The highest percentage of patients who have improvement after given low vision device was under the category of severe visual impairment $(100 \%)$ and followed by the category of moderate visual impairment which have improvement about 92.30\% (figure 3).

From 41 patients with low vision who were given spectacles, only 31 patients $(70.60 \%)$ gained improvements, whereas other 10 patients $(24.40 \%)$ did not. Out of 40 patients with low vision who were given stand magnifiers, only $35(87.50 \%)$ gained improvements whereas the other five patients $(12.50 \%)$ did not (figure 4$)$.

\section{Discussion}

In this research, it was revealed that the total number of patients with low vision treated during the period of August 2010-September 2011 was 475 patients, 212 patients were male whereas 263 were female. This is in accordance with previous studies conducted by the WHO, stating that women had more risks than men.

It was also revealed that the majority of patients with low vision were under the category of 11-20 years old, with 115 patients. However, this is not in line with a study conducted by the WHO, which stated that the number of patients with low vision were the same at all categories of age. This is probably caused by several possibilities: patients with low vision who came to the polyclinic at Cicendo Eye Hospital were referred patients, thus this result could not entirely describe the distribution of the number of patients to all categories of age.

Out of 475 patients with low vision, 81 patients were given low vision device for near vision, whereas the other 364 patients were not given since they had lower visual acuity measured by hand movement to no light perceptions. From out of the 81 patients given low vision device, only 66 patients or $81.48 \%$ gained improvements, which is in accordance with the study conducted by Tom H. Margrain

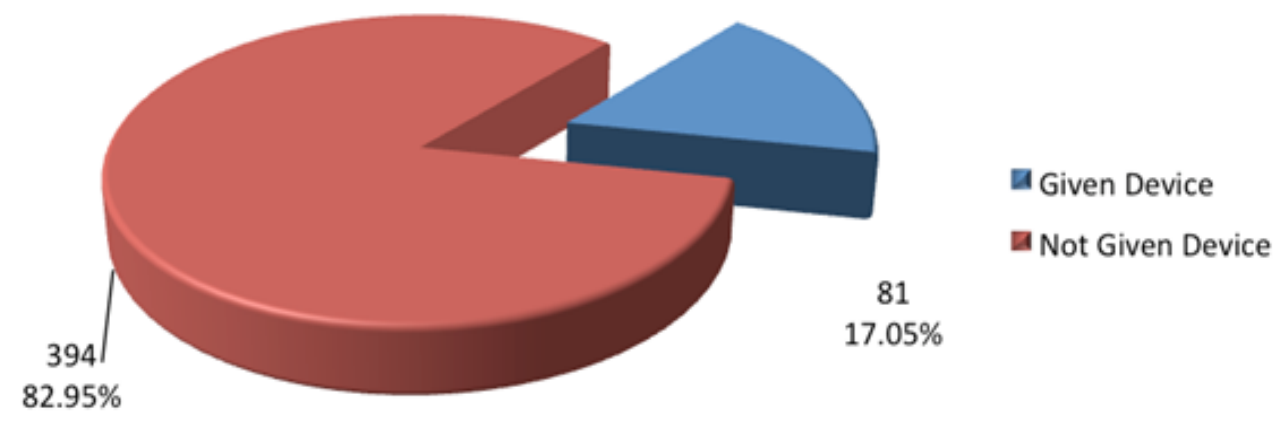

Figure 1 Frequency Low Vision Patients Given Corrective Device 


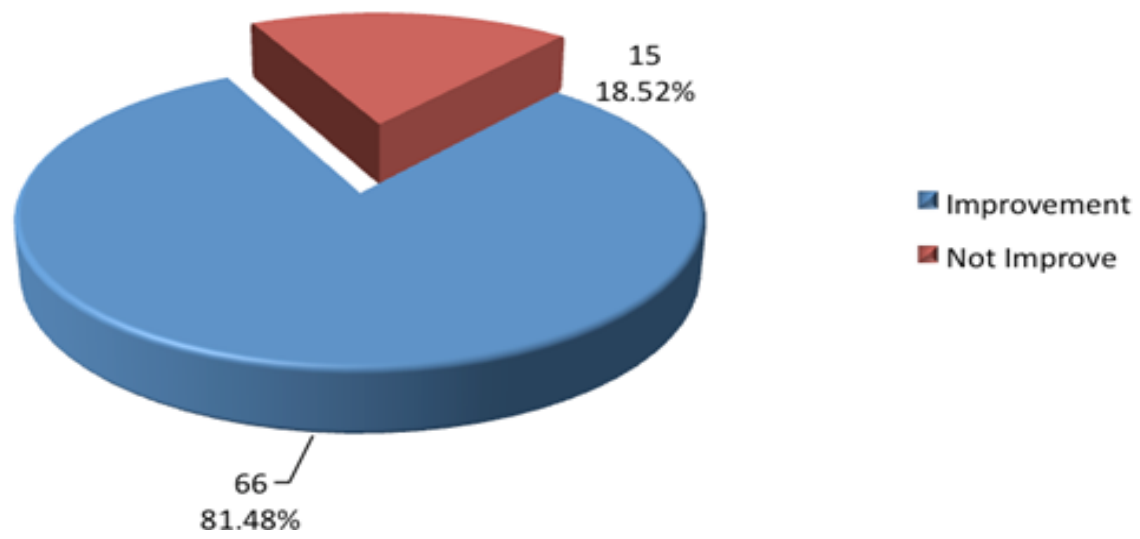

Figure 2 Frequency Based on Corrective Treatment Results after Corrective Device for Near vision were Given

that only $23 \%$ of patients with low vision could read 1 M-sized writings. After they were given a low vision device, $88 \%$ of these patients could read those writings. ${ }^{11}$

The visual acuity level that gained the most improvement percentage was under the category of severe visual impairment: $100 \%$. This was due to the fact that the number of patients under that category was the least if compared to those in other categories. Furthermore, the visual acuity of patients under the category of severe visual impairment was better than that of those under the category of profound visual impairment and near-total vision loss, thus the improvement percentage was better.

In this research,the low vision device $s$ used were magnifiers in the form of spectacles, and stand magnifiers. These devices were considered the best among others since they had been proven to improve visual acuity for near vision. This was in accordance with a study conducted in England, which stated that 9 out of 10 patients gained improvements in reading after they had been given such low vision device. ${ }^{11}$

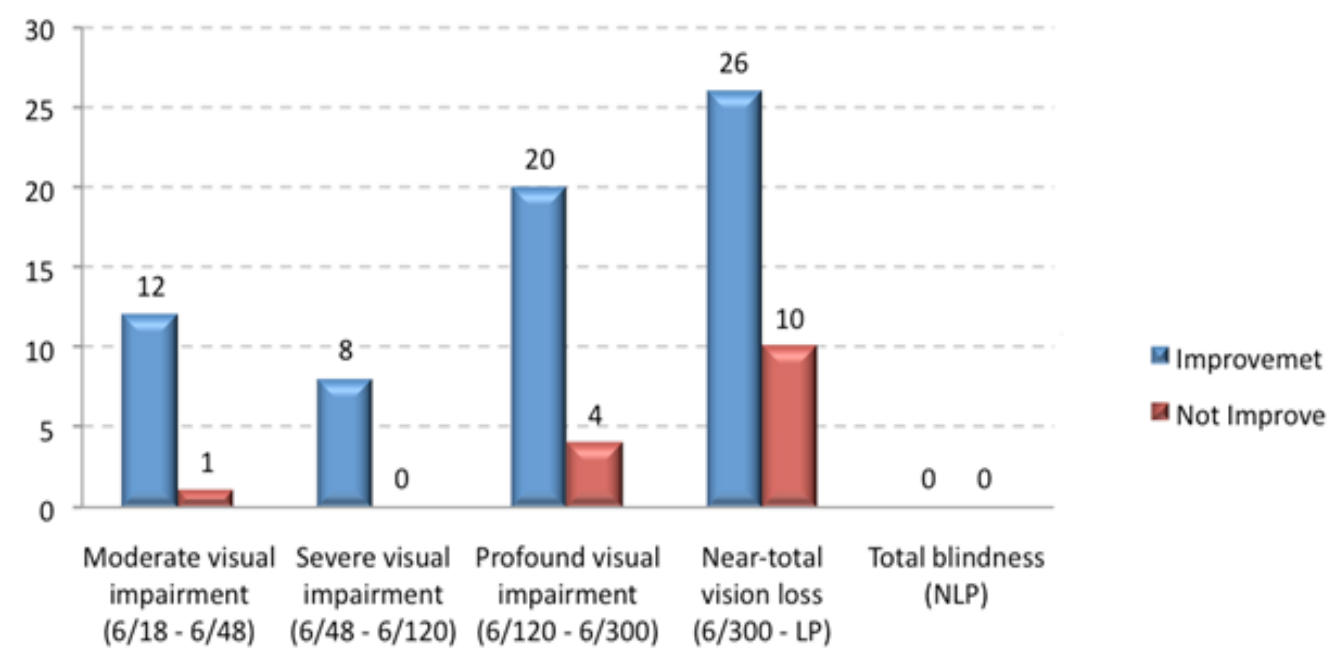

Figure 3 Frequency of Corrective Improvements on Patients with Low Vision, Based on Improvement Results 


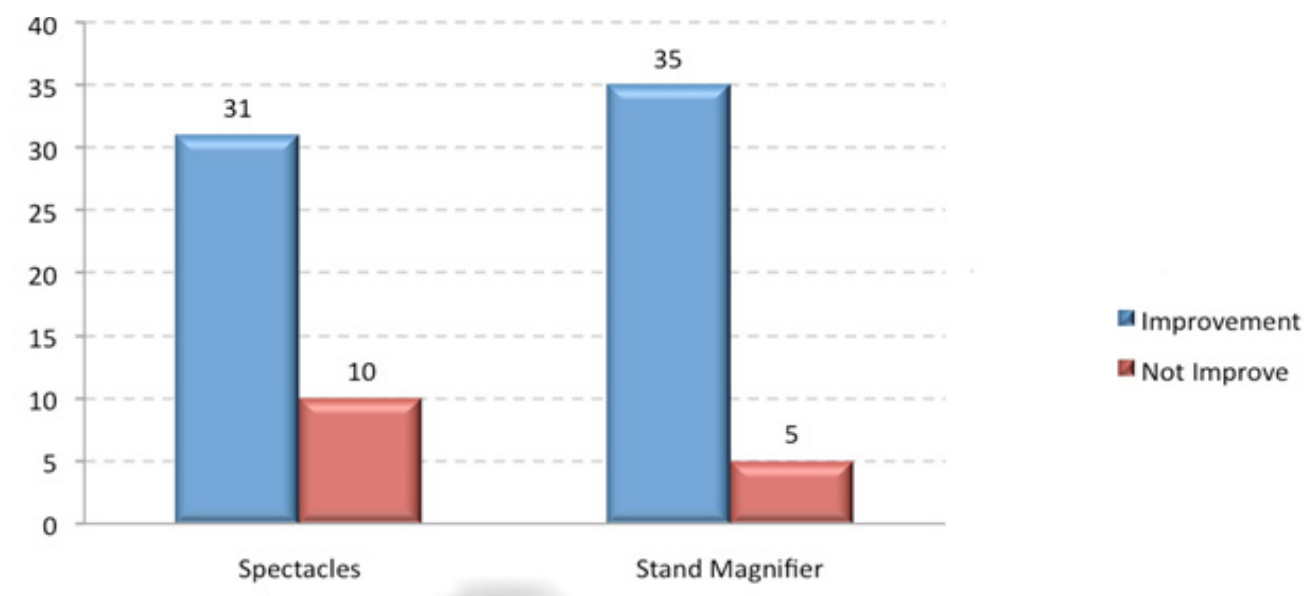

\section{Figure 4 Frequency of Low vision device for Patients with Low Vision, Based on Improvement Results}

In this research, it was mentioned that one of such devices that had the biggest percentage was the stand magnifier, since stand magnifiers have higher dioptric values than spectacles do. Stand magnifiers have dioptric values from $+16 \mathrm{D}$ to $+36 \mathrm{D}$, whereas spectacles only have dioptric values from $+3 \mathrm{D}$ to +20D. Furthermore, using spectacles can pose difficulties in maintaining focal length. Unlike spectacles, stand magnifiers have length-holders which allow us to maintain focal length, and users can read in a much better way. Another kind of low vision device is the hand magnifier, which was not used in this research due to its dioptric values rather similar to those in spectacles. Hand magnifiers also pose similar difficulties in maintaining focal length as spectacles do. Using such devices would be less practical since users should also use their hands to hold the device.

It can be concluded from this research that visual acuity for 1-10M will gain improvement after patients are given visual-aiding devices for near vision. The highest improvement percentage is the one under the category of severe visual impairment. It is suggested that further research should give attention to other factors causing low vision for improvements of near or far vision, improvement factors, as well as the patient's reading quality.

\section{References}

1. WHO. Visual impairment and blindness. 2011[cited 8 April 2012]; Available at: http://www.who.int/mediacentre/ factsheets/fs282/en/.

2. American Academy of Ophthalmology. Optics of human eye. Clinical optics, 4th ed. San Fransisco: AAO; 2009, p.105-115

3. Congdon N OCB, Klaver CC, Klein R, Muñoz B, Friedman DS, Kempen J, Taylor HR, Mitchell P Causes and prevalence of visual impairment among adults in the United States. UK Pubmed Central. 2004.

4. Hosni I. Konsepdasar low vision; pelatihan guru low vision se Jawa Barat; 24 Juli 2007; Bandung. Jawa Barat: Unit PelaksanaTeknisBalaiPelatihan Guru SekolahLuarBiasaDinasPendidikanJawa Barat; 2007.

5. Miller KM. Clinical Optics. 3th ed. San Fransisco: America Academy of Ophthalmology; 2007, p.243-67

6. Fletcher DC. Low Vision Rehabilitation. Ophthalmology Monographs. San Fransisco; America Academy of Ophthalmology; 1999, p.1-133

7. Kageyama JY, Chun MW. Video-Based Low Vision Devices. Duane's , Clinical Ophthalmology. Chicago; J. B. Lippincott ; 2004, p.1-8

8. Khurana AK. Community Ophthalology. Comprehensive Ophthalmology, 4th Edition. Rohtak; Ahnsan Pub; 2008, p.443-4

9. Faye EE. Duane's Clinical Ophtamology. Michigan: Little, Brown; 2004. p. 1-46

10. Hinds A, Sinclair A, Park J, Suttie A, Paterson $\mathrm{H}$, Macdonald M. Impact of an interdisciplinary low vision service on the 
quality of life of low vision patients. Br J Ophthalmol. 2003 Nov;87(11):1391-6

11. Margrain TH. Helping blind and partially sighted people to read: the effectiveness of low vision aids. Br JOphthalmol. 2000 Aug;84(8):91-121 